\begin{tabular}{c} 
Volume and Issues Obtainable at Center for Sustainability Research and Consultancy \\
Journal of Accounting and Finance in Emerging Economies \\
ISSN: 2519-0318 ISSN (E) 2518-8488 \\
Volume 5: Issue 2 December 2019 \\
CSRᄃ \\
Journal homepage: www.publishing.globalcsrc.org/jafee \\
\hline
\end{tabular}

\title{
Islamic VS. Conventional Commercial Banking: The Resilience Avant-Garde
}

\author{
${ }^{1}$ Areeba Khan, ${ }^{2}$ Imran Sharif Chaudhry, ${ }^{3}$ Sohail Saeed \\ ${ }^{1}$ The Islamia University of Bahawalpur Pakistan: areeba.khan@iub.edu.pk \\ ${ }^{2}$ Bahuddin Zakariya University Multan Pakistan: imran@bzu.edu.pk \\ ${ }^{3}$ The Islamia University of Bahawalpur Pakistan: sohail.saeed@iub.edu.pk
}

\begin{tabular}{l}
\multicolumn{1}{c}{ ARTICLE DETAILS } \\
\hline History \\
Revised format: November 2019 \\
Available Online: December 2019 \\
\\
Keywords \\
Islam, Islamic Banking, \\
Comparison, Resilience, Z-Score, \\
Liquidity Conversion Ratio
\end{tabular}

JEL Classification:

$J 10, D 60$

\section{ABSTRACT}

This paper aims to examine the differences in financial resilience of Islamic and Conventional Commercial banks with respect to the short term and long-term perspectives to pliability. The selected banks are compared on their resilience quotient exhibited by Liquidity Coverage Ratio (LCR) and Z-Scores. This study evaluates cross country panel data of 157 listed and non-listed licensed Islamic banks located in 22 countries and same number of their conventional commercial counterparts, through a period of 1998 to 2018. The data were collected through BANKSCOPE database and World Bank publications. Ratio analysis and Multiple Regression analysis were applied on data to analyze the extent of resilience of both Islamic and Conventional banks. The findings suggest that there are considerable differences in short term and long term resilience quotient of Islamic and Conventional commercial banks. Where Islamic banks have relatively enervated position than Commercial banks on liquidity frontier, they hold a more resilient position with respect to zscore. ROE and Capital adequacy are two important factors that have a significant impact on bank resilience. This research is different from all past researches with respect to methodological, aeon and acclimatization perspective. Resilience is a relatively new phenomenon adopted from complex adaptive ecosystems and most studies in this area are of theoretical nature. Moreover, the fact that this research has considered not only the long term but also short-term resilience perspective, adds to its overall value and originality.

(C) 2019 The authors, under a Creative Commons Attribution-Non Commercial 4.0

Corresponding author's email address: imran@bzu.edu.pk

Recommended citation: Khan, A., Chaudhry, I. S, and Saeed, S., (2019). Islamic Vs. Conventional Commercial Banking: the Resilience Avant-garde. Journal of Accounting and Finance in Emerging Economies, 5 (2), 261-274

DOI: $10.26710 /$ jafee.v5i2.921

\section{Introduction}

In the wake of Global Financial Crisis (GFC), the world saw incipient trends in banking and finance. Commercial banking had lost its credibility and a major gap sprouted in the financial system, an expanse which was to be covered by the inchoate of Islamic finance. Considered more stable and efficient in theory, the Islamic banks (IBs) were well received by the investors all over the world as an ethical alternative to conventional commercial banking. 
Since then, the Islamic and Conventional commercial banks (CBs) have been compared to each other with respect to various aspects of efficiency. The GFC itself was a testimony on inefficacy of efficiency as a performance measure. There was need of a mechanism, which may not only reflect on efficiency of a system but also predict its tenure of stability and growth momentum; in short, it must predict its resilience quotient.

The comparative paradigms of Islamic and Conventional commercial banks have never been assessed on the resilience perspective. Theoretical arguments support a more resilient stature of Islamic banks as compared to conventional commercial banks, but there is lack of empirical evidence to support the same. Moreover, factors affecting bank performance, especially the their relative resilience quotient are also widely unexplored.

C.S. Holling (1973) was the person who introduced the word 'resilience' to the field of ecology. It is supposed to represent the return time of a system to its original position and better after a period of unprecedented turmoil. This return time of the system depends on the adaptive capacity of the system to tackle the perturbation and overcome it.

A resilient system exhibits several stable equilibrium points over a period of time, which is explained by equilibrium succession. Subject to change in the environment, the system gets disoriented first then tries to conserve its core competencies and move on towards the creative destruction phase as soon as possible. Reorganization follows creative destruction where the features, structure and identity of the system arrange themselves in an even better configuration. Therefore, we may describe resilience as a stochastic process inherent in a system. This process gets activated by external shocks and unprecedented changes in the environment. Panarchy of the system calls for a detailed analysis of elasticity and precariousness to establish the system's resilience magnitude (resilience quotient).

A concept new to the field of finance, resilience made its way to the regulatory documents and keynote addresses of the monitoring authorities fairly soon. Financial resilience is not considered a buzzword anymore, but an essential phenomenon signifying stability of any system and its subsequent persistence at multiple equilibriums. As used by BASEL III accord, financial resilience is ability of a bank to withstand changes in the environment, absorb external shocks and manage to bring itself back to its initial equilibrium, or an advanced one in a shorter period. Earlier on, efficiency was considered the heart of performance analysis of banks. Resilience however, has now replaced efficiency as the core of performance analysis, since resilience not only encompasses the efficiency perspective but also stability and growth potential.

All through the late worldwide financial crisis, IBs have exhibited strength (Farook, Hassan, \& Clinch, 2012) confirm by moderately high development execution of this industry and a genuinely stable level of NPF. Be as it may, there are variables considered "protecting" the IBs from the immediate effect of stuns in the worldwide monetary framework i-e presentation of Islamic financing was still more outfitted to the conventional economy. Then again, as (Beck, Demirgüç-Kunt, \& Merrouche, 2013) calls attention to, the IBs might have been strong in GFC first wave, they are presented to higher danger in the delayed repercussions of emergency inferable from their meeting with business banks, on a few practices that render them more powerless against financing cost stuns and expanded systemic danger.

So far the world has seen the disappointment of extensive foundations of conventional banking system whereas IBs have not been put to a corrosive test of strength as their routine partners. Seen from a functional periscope, IBs are a subject to financing cost chance as well, notwithstanding intemperate liquidity hazard emerging from resource and obligation administration works on, inferable from the imprint up based contracts, the duality of agreements offered and reliance on traditional managing an account framework without a steady and all around created cash and capital business sector.

The majority of the studies, capital adequacy and income are observed to be the most helpful pointers of the likelihood of bank failure (Demirguc-Kunt \& Huizinga, 1989). Likewise, fast extension of loaning exercises tends to increment credit risk (Keeton 1999). More expound displaying, which recognizes the probability of default and time to default, finds that fundamental pointers of a bank's condition, for example, capital, net income and retained earnings are likewise imperative determinants of the timing of bank default (Cole \& Gunther, 1993).

The relating question here is, can a bank that keeps up a decent capital adequacy ratio and great productivity level file for default? The answer is yes. Global financial crisis of 2009 saw the calamity of banks with an appropriate 
capital adequacy ratio and profitability levels, petitioned for chapter 11. In such a situation, what is the prescient limit of capital adequacy ratio and profit efficiency as standalone supporters to execution assessment? There must be something missing. The answer is resource quality, influence and liquidity. These are the viewpoints terribly overlooked by a number of the productivity and benefit scientists.

Another rather intriguing issue is whether non-money related pointers like ownership status of a bank have the capacity to foresee its strength and benefit? Little proof is found to bolster the hypothesis that exclusive establishments will return moderately higher financial benefits. (Short, 1979) is one of only a handful few studies offering cross-country confirmation of a solid negative relationship between government proprietorship and bank profitability. In his late work, (Barth, 2001) claims that administration responsibility is surely adversely connected with bank effectiveness. Interestingly, (Bourke, 1989) and (Molyneux \& Thornton, 1992) report that proprietorship status is insignificant for clarifying productivity. In any case, this territory needs more investigation and constitutes an intriguing part of study that may not just give an understanding on the corporate administration structure of bank additionally choice making systems.

Therefore, prime objective of study is to analyze whether IBs are different with respect to their Commercial Banking counterparts regarding financial resilience. The specific objectives contributing to this are as follows:

- To analyze if there exists any difference between short term financial resilience of Islamic and CBs.

- To analyze if there exists any difference in Long term Financial Resilience of Islamic and CBs.

- To analyze how Financial Resilience is affected by firm and industry specific factors in comparative banking paradigms.

The paper is organized as follows. Section 2 briefly discusses the literature on resilience and its use to measure stability of a banking firm. Section 3 describes Z-Score as the financial resilience quotient measurement model and its application to Islamic as well as conventional commercial banks. Section 4 discusses the results of application of Z-Score and normative differences of both the paradigms ascertained through it, over the period of 1998-2014. Finally, Section 5 concludes.

\section{Brief Review of the Literature}

What can be described as the foundation of Islamic financial system was, till the end of the nineteen-seventies, to a great extent a supplication for supplanting enthusiasm for bank credit by profit and loss sharing. This would change the way of money related intermediation, making the asset proprietors and additionally the budgetary delegates impart the risks of investments to the asset clients. Early literature in this aspect has focused on accentuation of reasonableness. Making the investor and the bank share the risk of business and bank guarantee a foreordained return was termed unfair. Since the manner in which the venture was led did not assurance a positive return, so there was no legitimization for cash capital guaranteeing a positive return regardless of the aftereffects of operations, it was contended by the protagonists of Islamic banking (Siddiqui, 2006).

Quite missing were hypothetical contentions to guarantee the investors with respect to the security of their finances, past the general contention that some sort of 'mutual insurance' will deal with the issue. Additionally, little consideration was paid to what later was known as 'trade based modes of finance' (Hussein, 2004).

In the advancement of hypothesis of Islamic finance, the late seventies and the eighties saw numerous critical commitments. Murabahah or cost in addition to financing, recognized just grudgingly in records, for example, the Islamic Ideology Council of Pakistan Report on Elimination of Interest from the Economy, earned full acknowledgment and additionally respectable method of reasoning. The debate around its authenticity (Vogel and Hays 1998; Warde 2000) or its adequacy scarcely had any effect on the velocity with which it vanquished the scene of Islamic money.

IBs are additionally confronted with operational risks in running a framework in compliance with Shariah rules. The majority of the analysts place IBs at a more risky position than the CBs with respect of operational and credit risks especially in markets where there is less acquiescence for religiosity (Hasan \& Dridi, 2010).

The majority of the studies on capital adequacy and profit efficiency are observed to be the most helpful predictors of the likelihood of bank failure (Demirguc-Kunt \& Huizinga, 1989). More in depth studies focusing on the 
probability of default and time to default, find that fundamental indicators of a bank's efficiency, for example, capital, net income and retained earnings are likewise imperative determinants of the timing of bank default (Cole $\&$ Gunther, 1993). In any case, the nub of the matter has been for the most part lost. Capital adequacy proportion is to a greater degree a conformance issue. Banks need to consent to the prudential regulations and keep up a point of confinement of capital adequacy proportion. Same is the case with profitability. Banks seek all means to accomplish most extreme profit efficiencies. The most relevant question here is, can a bank that keeps up a decent capital adequacy ratio and an adequate productivity level file for default? The answer is yes. Global financial crisis of 2009 saw the calamity of banks with an appropriate capital adequacy ratio and profitability levels, petition for chapter 11.

There is, however, broad exploration in the elements that might influence bank performance and their relative impact on bank stability. There are two types of bank performance determinants: macroeconomic variables (systemic risk) and firm-particular elements (non-systemic). There is a broad body of literature that looks to distinguish bank variables which may prove to be the best indicators of bank execution. Subsequent to the main part of this examination has been done in the US (with its vast populace of banks and long history of bank disappointments), the work for the most part spotlights on displaying the probability of bank disappointment.

The Macroeconomic variables ordinarily used to determine performance volatility are the inflation rate, the interest rate and/or the development rate of cash supply. Revell (1979) presents the issue of the relationship between bank profitability and interest and inflation rate. Most studies, including those by Bourke (1989) and Molyneux and Thornton (1992) have demonstrated a positive relationship between either inflation or interest rate and yields.

\section{Research Methodology}

Banking research around the world has made an extensive use of bank level data provided by Thompson's Bankscope. On similar notes, this research relies primarily on data from Bankscope. For the purpose of this study the IBs' data is utilized which have been licensed as IBs compared with a comparable sample of Commercial banks. The total population of active IBs on Bankscope is 157. This study takes into consideration a total of listed IBs and 100 non listed IBs in 22 countries and their commercial banking counterparts for the period from 20002013.

The research framework developed for the purpose of this study builds on Z-score, recently used by Hesse \& Cihak (2007) along with ratios from Basel II and Basel III accords taken at risk adjusted foundations and ownership analysis by Bonin et al (2005). Cihak and Hesse \& Cihak (2007) use z - score as a measure of individual bank risk, following its utility for other similar studies carried out by Boyd and Runkle in 1993 among others.

As per Basel II, resilience can be divided into two components; Long term financial resilience and Short Term financial resilience and could be constituted through Capital and Liquidity buffers, Profitability and Good governance.

In order to promote the Short-term resiliency of liquidity risk profile of institutions by ensuring that they have sufficient high quality liquid resources to survive an acute stress scenario lasting at least for one month, the Basel Committee developed Liquidity Coverage Ratio.

$$
\text { LCR }=\frac{\text { Stock of highly liquid assets }}{\text { Net Cash Outflows over a } 30 \text { day time period }} \geq 100 \%
$$

Since Net Cash outflows are not being publicly maintained by banks, total current deposits would perform as proxy of monthly cash outflows. The ratio will be ascertained to have warranted significance through Independent sample $t$ test applied to it. Independent sample $t$ test will provide for the total amount of error involved in using 2 sample means to estimate 2 population means. It signifies the average distance between the sample difference (x1$\mathrm{x} 2)$ and the population difference $(\mu 1-\mu 2)$, therefore succor in achievement of the afore mentioned objective.

The variable used for determination of Long term Financial Resilience is z score. Z-Score has become an important measure of bank soundness (Beck et al., 2013). Its popularity stems from the fact that it is inversely related to the 
probability of a bank's insolvency. i-e the probability that value of its assets falls lower than the debt it carries. The $\mathrm{Z}$ - score can be summarized as $\mathrm{z}=(\mathrm{k}+\mathrm{u}) / \mathrm{s}$, where $\mathrm{k}$ is the equity capital and reserves as a percentage of assets, $\mathrm{u}$ is average return as a percentage of assets and $\mathrm{s}$ is standard deviation of returns on assets as a proxy for return volatility.

The z-score measures the number of standard deviations a return realization has to fall in order to deplete equity, under the assumption of normality of bank's returns. A higher z-score corresponds to a lower upper bound of insolvency risk- a higher z-score therefore implies a lower probability of insolvency risk (Beck et al, 2013).

The definition of z-score (Yeyati and Micco, 2007) is as follows:

$$
\text { Zit }=\mu \mathrm{ROA}+\left(\frac{\text { Eit }}{\text { Ait }}\right) / \sigma \mathrm{ROAit} \quad(\text { Eq. } 4.2)
$$

Where Zit is the proxy variable for the probability of insolvency of the bank I at time t, ROAit is the ratio of return on assets of bank I at time t, Eit /Ait is the amount of equity to assets ratio of bank I at time $t$, and $u$ and $s$ are the mean and variance of the ROA it distribution.

\section{Results}

\subsection{Short term Financial Resilience}

The LCR is characterized as the proportion of the highly liquid assets for the aggregate net outflows throughout the following 30 schedule days in crisis:

\section{Highly Liquid Assets/Total net outflows for 30 days $>1$}

The numerator of the LCR is the "load of Highly Liquid Assets (HQLA)". Under the standard, banks must hold a load of unengaged HQLA to cover the aggregate net cash outflows (as characterized underneath) over a 30-day period under the endorsed crisis situation. With a specific end goal to qualify as "HQLA", resources ought to be liquid amid a period of financial distress and, in a perfect world, be central bank qualified. These are the essential characteristics that the liquid assets ought to have in order to be qualified for being highly liquid assets. This proportion is required to be above $100 \%$. The estimation of LCR relies on upon the estimation of supply of liquid assets and the aggregate net money outflows. These presumptions incorporate the order of "Level 1" and "Level 2" resources, the weights relegated to these advantage classes, the arrangement of distinctive risk classifications, and the rates of money outflows and inflow for diverse liability classifications. The graph also negates the widely held belief that Islamic banks face higher liquidity risk than their commercial counterparts, as 2006 to 2013 witnesses a relatively stable liquidity conversion ratio, keeping in range of 2 to 3.5, which is well above the basic requirement set by BASEL III of $100 \%$, but still manageable in the liquidity and profitability tradeoff. A linear extrapolation of the LCR trend line reveals a stabilized coverage of all liquid current liabilities, keeping above 2.5 times coverage range.

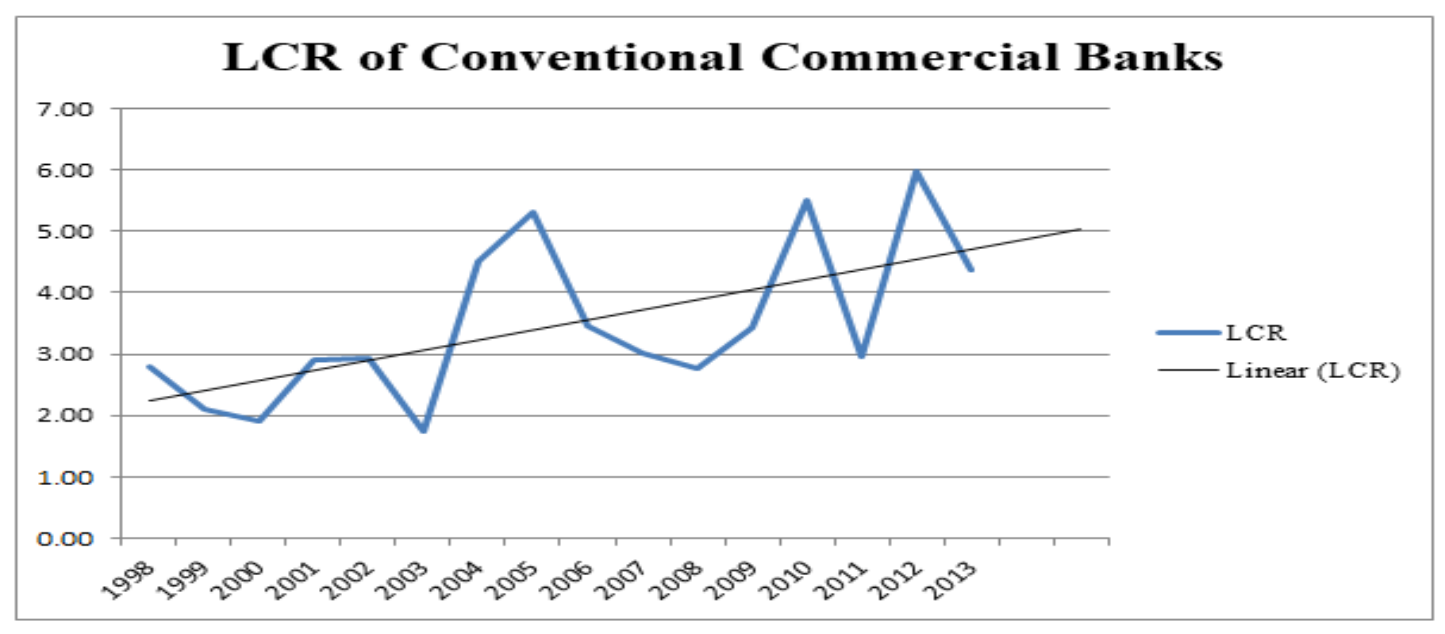

Figure: 1 LCR OF CONVENTIONAL COMMERCIAL BANKS 
This shows that there was a downfall in bank liquidity even before the Global Financial Crisis of 2009. The situation had started worsening as early as late 2005 and escalated quickly to a financial crisis in 2009.Comparing both the alternative banking systems, it is evident that Conventional commercial banks witnessed a sharp surge in LCR from year 2003 to 2005, which corrected itself in 2005 and onwards, plunging down much to burst the bubble created by hiked overvaluation of assets of commercial banks, marking a financial crisis in 2009. On the other hand, Islamic banks do not show any signs of turmoil during the period and maintain relatively resilient liquidity levels.

Table: 1

\begin{tabular}{lll}
\hline Descriptive & LCRISL & LCRCM \\
\hline Mean . & 2.674 & 3.482 \\
Standard Deviation & 0.739 & 1.290 \\
\hline
\end{tabular}

As per periodogram, the Islamic banks show lesser variation in time series of LCR even if the crisis effect was ignored. Moreover, Islamic banks seem to attain better liquidity coverage after crisis, therefore showing more resilience. These results are also confirmed by the higher mean and higher standard deviation on Conventional banks. Conventional banks have almost 3.5 times coverage of the current outflows for a period of at least a month, improving drastically in the post crisis period whereas Islamic banks have a mean LCR of little above 2.5. The variability in liquidity coverage by Conventional commercial banks is more, exhibited by the standard deviation of 1.29 as compared to 0.739 in Islamic banks.

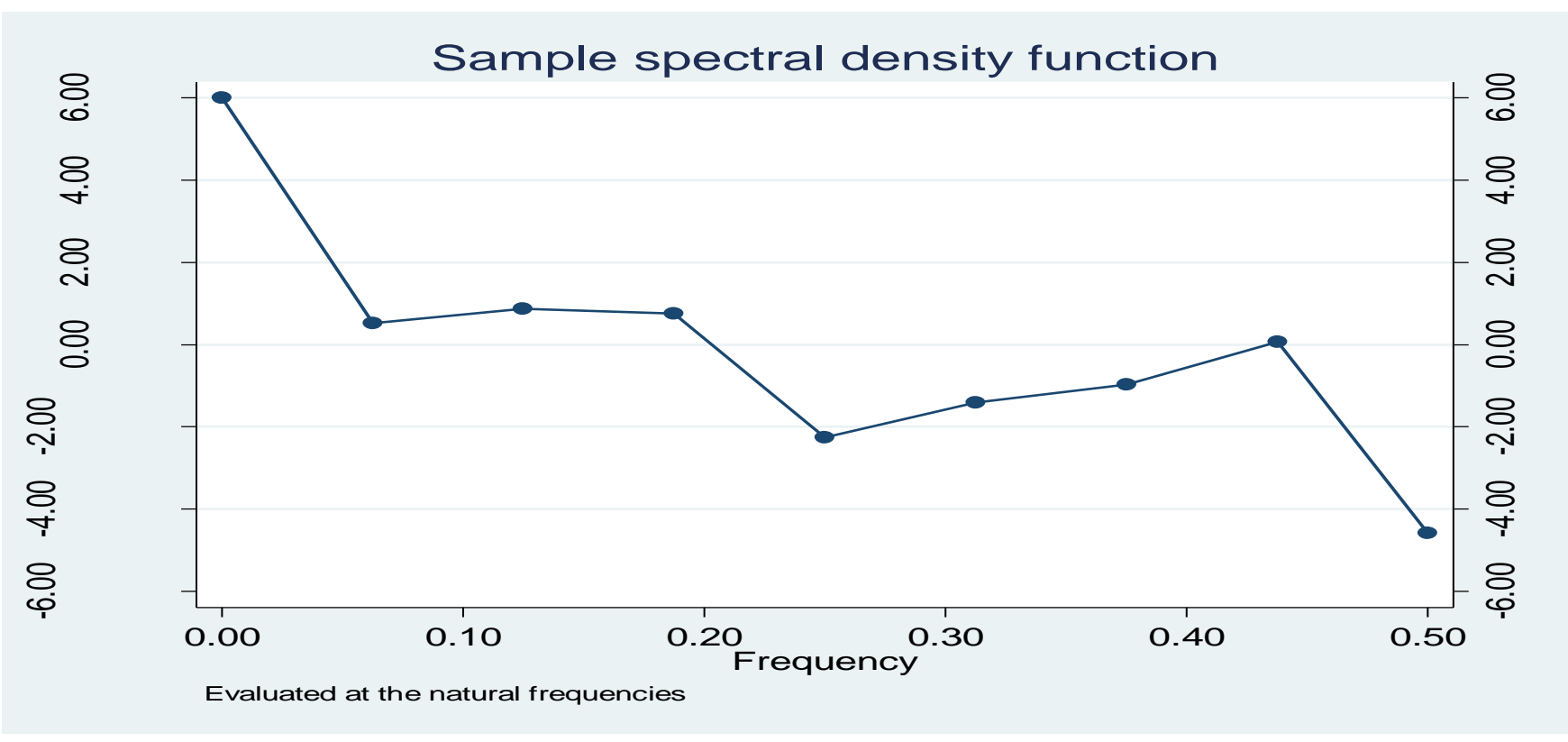

Figure: 2 Periodogram of LCR for Commercial Banks

The above analysis has proven LCR to be an important apparatus in gauging the financial distress of a banking company however it must be used with tremendous care to ensure the efficacy of the forewarning signals for financial rigor. The dimensions of LCR render it diminutive efficiency with respect to efficiency, and must be controlled for the compliance prejudice. 
Basel III supported haircuts to different categories of assets may be applied to craft the risk weighted portfolio of liquid assets to the variance witnessed in the LCR of banks over time, as not only the shortage of liquidity but variance in liquidity levels may also lead to liquidity stress in financial institutions.

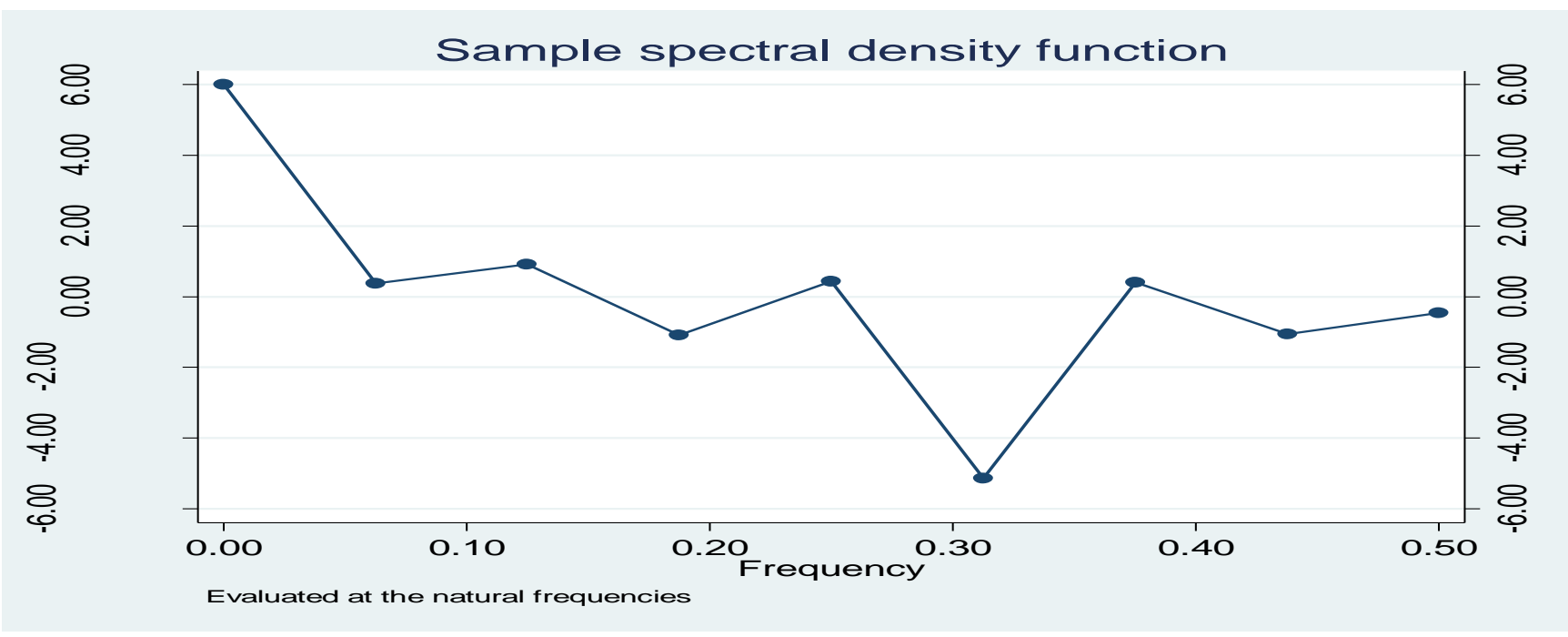

Figure: 3 Periodogram of LCR of Islamic Banks

However, there is a marked decrease in Islamic bank liquidity, as compared to conventional banks in recent couple of years, bring the average liquidity down to 2.674 as compared to 3.482 of conventional commercial banks. However, the volatility and variability of LCR is low in Islamic banks over the period taken into consideration as marked by a standard deviation of 0.739 , compared to 1.290 of Conventional Commercial Banks, parading stability with respect to short term liquidity.

Table: 2 Factors affecting LCR of banks

\begin{tabular}{|c|c|c|c|c|c|}
\hline Model & Unstandardized & Coefficients & $\begin{array}{l}\text { Standardized } \\
\text { Coefficients }\end{array}$ & $\mathbf{t}$ & Sig. \\
\hline & $\mathrm{B}$ & Std. Error & $\mathrm{B}$ & & \\
\hline (Constant) & 0.3441 & 2.380 & & 1.446 & 0.151 \\
\hline OWNR & 0.879 & 1.104 & 0.076 & 0.796 & 0.151 \\
\hline ROA & 0.104 & 0.124 & 0.078 & 0.842 & 0.402 \\
\hline CARWTD & 0.097 & 0.033 & 0.286 & 2.984 & $0.004 * *$ \\
\hline TOTASSETS & 0.001 & 0.000 & 0.129 & 1.427 & 0.157 \\
\hline NPLTOGL & 0.024 & 0.049 & 0.053 & 0.485 & 0.629 \\
\hline ROE & 0.094 & 0.057 & 0.200 & 1.651 & $0.100 *$ \\
\hline COSTTOINC & -0.034 & 0.019 & -0.221 & -1.770 & $0.080 *$ \\
\hline
\end{tabular}


Model Summary:

$$
\mathbf{L C R}=\beta+\beta_{1} B_{i j t-1}+\varepsilon
$$

R2 : 0.403

Dependent Variable: LCR

Predictors: (Constant), OWNR (Ownership), ROA (Return on Assets), CARWTD (Capital adequacy ratio calculated on risk weighted assets of the bank), TOTASSETS (Total Assets of the bank), NPLTOGL (Nonperforming loans to gross loans), ROE (Return on equity), COSTOINC (Calculated by dividing cost to income).

However, since liquidity needs to be held for the committed undrawn products, banks have to manage it in order to avoid a bank run. Therefore, it may or may not be a product of banking institutions' operations, as is evident by the regression analysis.

Analysis of Firm specific factors affecting liquidity of a banking company, highlight some important corollaries. First and foremost being the fact that it's not only firm specific factors that may impact the liquidity of a bank, but also the presence of a good money and call market, as well as country wide liquidity reserve requirements, interbank lending arrangements, and Government borrowing. Macroeconomic factors may also have a significant impact on liquidity of a banking firm, however, segregating that impact from business specific factors may be very difficult for the purpose of analysis owing to maturity mismatch.

These reasons account for the low explanatory power of the model, as R2 lies barely above 0.403 , highlighting that just little above $40 \%$ of overall variation is explained by the business specific factors. The banal power of R2 however is debatable some of the variables stand significant at a level of $10 \%$ and $5 \%$. Weighted capital adequacy ratio (CARWTD) stands significant in as a determinant of LCR stands significant at a level of 5\% which exhibits the effect of not only capital adequacy requirements but also the risk appetite of the firms. ROE and Cost to Income also stand significant at a level of $10 \%$, whereas the direction of impact of Cost to income is negative in case of banks, translating to an escalated impact on bank liquidity with control of cost of operations.

\section{Z-Scores of IB vs CB}

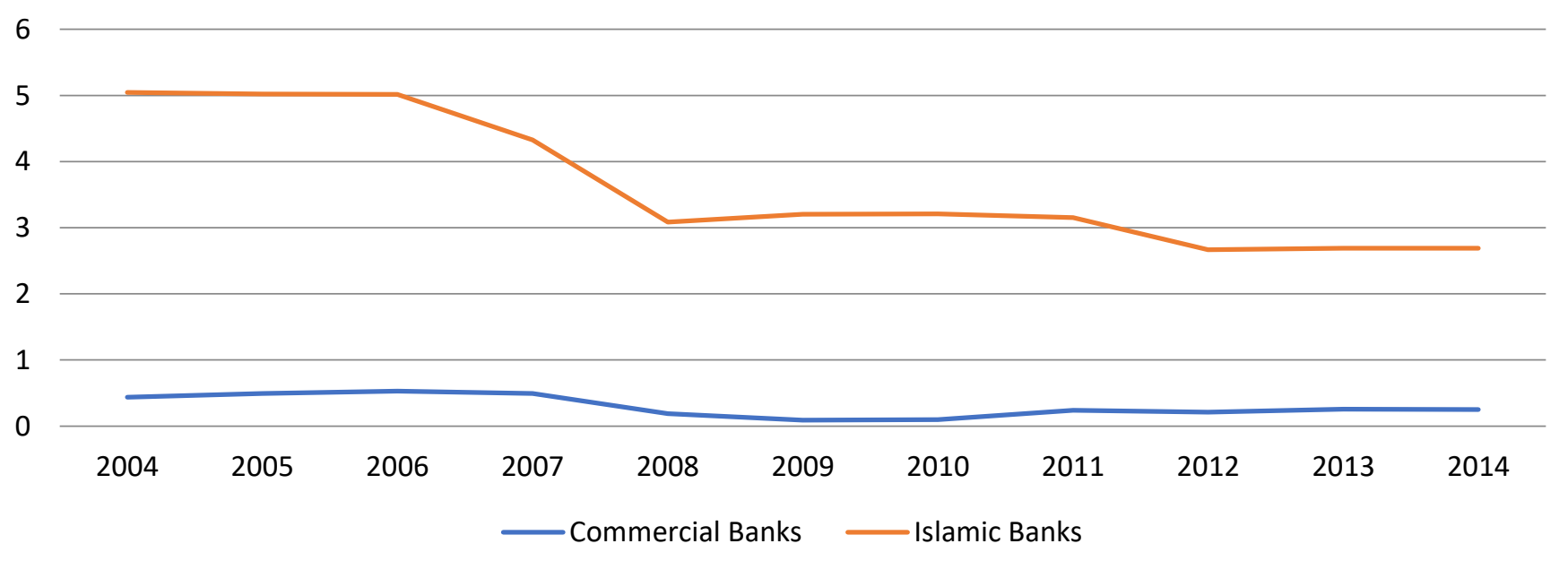

Figure 5 Z-Score of IB vs CB

The average z-scores of Islamic banks are compared to Conventional Commercial banks operational at least over the period of last decade are taken into consideration, for an average trend of mature financial institutions from both the domains. The foremost in the basic observations in the long term resilience trend is that most of the Islamic banks started with a very strong financial position. The capital base was larger as compared to the mainstream banks as well as liquidity portfolio. Returns were also significantly higher as compared to the commercial counterparts, partly owing to the Islamic brand name. The asset liability management practice seems to tone the financials down to a more realistic level. 
Table: 3 Factors affecting Z-Score of banks

\begin{tabular}{|c|c|c|c|c|c|}
\hline Model & Unstd. & Coefficients & Std. Coefficients & $t$ & Sig. \\
\hline & B & Std. Error & B & & \\
\hline (Constant) & 3.319 & 4.649 & -- & 2.118 & $0.035 * *$ \\
\hline OWNR & -5.861 & 4.002 & -0.071 & -1.464 & 0.146 \\
\hline $\mathrm{ROA}$ & 0.041 & 0.019 & 0.269 & 2.203 & $0.028 * *$ \\
\hline CARWTD & -0.485 & 0.122 & -0.201 & -3.984 & $0.000 * * *$ \\
\hline TOTASSETS & -0.001 & 0.000 & -0.020 & -0.428 & 0.670 \\
\hline NPL TOGL & -0.058 & 0.185 & -0.018 & -0.312 & 0.755 \\
\hline $\mathrm{ROE}$ & -0.102 & 0.210 & -0.030 & -0.485 & 0.629 \\
\hline LCR & 0.251 & 0.349 & 0.035 & 0.718 & 0.474 \\
\hline COSTTOINC & 0.098 & 0.071 & 0.088 & 1.375 & 0.172 \\
\hline MACVECT & 2.636 & 2.597 & 2.521 & 3.325 & $0.001 * * *$ \\
\hline
\end{tabular}

The trend line seems to suggest that the historic belief that Islamic banks are more resilient than Commercial banks is true. The graph shows the efficacy of z-score as an early warning signal of firm's deteriorating financial health and low resilience. Before crisis, the z-scores of commercial banks started decreasing in 2007, which marked the onset of crisis.

$$
\mathrm{Z}_{\mathrm{ijt}}=\beta+\beta_{1} \mathrm{~B}_{\mathrm{ijt}-1}+\beta_{3} \mathrm{M}_{\mathrm{j}, \mathrm{t}-1}+\varepsilon
$$

Model Summary:

R2 : 0.788

Dependent Variable: $\mathrm{Z}$ score

Predictors: (Constant), OWNR (Ownership), ROA (Return on Assets), CARWTD (Capital adequacy ratio calculated on risk weighted assets of the bank), TOTASSETS (Total Assets of the bank), NPLTOGL (Nonperforming loans to gross loans), ROE (Return on equity), LCR (Liquidity coverage ratio), COSTOINC (Calculated by dividing cost to income).

The weighted capital asset ratio (CARWTD) was expected to have a positive sign ( Pasiouras \& Kosmidou, 2007), which has been proven by analysis. The implication of weighted CAR being significant for z-score is quintessential to the idea of corporate and regulatory controls exercised on the bank. Return on Assets (ROA) is taken as a measure of profitability in the model. The profitability of banking company with respect to assets is theoretically supposed to improve the financial health of the firm and result in better financial resilience. Return on Equity (ROE) is another measure of profitability. It has more implication in case of Islamic banks as most of arrangements of Islamic finance have a real asset base. It is also worthy of discussion how ROE of banking companies may serve 
both as profitability as well as efficiency measure. The ROE in this model isn't significant and implies a nonlinear relationship with the dependent variable z-score.

Table: 5.4 Z-Score of IB vs CB

\begin{tabular}{|l|l|l|l|l|}
\hline Variable & Minimum & Maximum & Mean & Std. Deviation \\
\hline Z-Score ISL & -7.39 & 101.44 & 8.722 & 16.18 \\
\hline Z-Score Com & -0.66 & 59.43 & 4.42 & 9.66 \\
\hline
\end{tabular}

Non-Performing Loans to Total Assets is another measure of efficiency of the banks. The sign of the relationship between z-score and NPL is negative which is in line with the expected results, since more non-performing loans only mean lesser efficiency and in turn, lesser resilience on part of banks. NPL for this model however hasn't turned significant, which may reflect on efficiency of banking recovery operations regardless the type of banks. The Macroeconomic vector, consisting of interest rate, inflation, exchange rate and is significant for the bank resilience, which elucidates on banking sector strength and resilience being explained by the macroeconomic indicators. However, it is still a question whether

Ownership signifies the nature of control exercised over the banks. It has also turned out to be insignificant, owing to the fact that most banks are not allowed to fail, especially Islamic banks in Islamic republics are usually supported by their respective Governments in event of financial distress.

The overall explanatory power of the model is $78.8 \%$ which parades the elucidatory dominion of the model. Business vector (BV) has been shown to have a positive relationship with the z-score. BV is calculated by developing a vector of all business related factors. According to the vector, the mean of all variables is zero and the standard deviation is of 1 . This creates a log normal distribution with no white noise. This positive and direct relationship between $\mathrm{BV}$ and $\mathrm{z}$-score validates the idea that business related factors have a direct and significant impact on z-score of banking firms. The variance of Oscillations exhibit a more positive momentum in the safe precinct as compared to the hazard precinct, which may be a sign of relative financial resilience as the bank experiences more frictions sliding in to the hazard precinct from the safe precinct. The effect of business vector on Islamic and Conventional Commercial banks is segregated to have a better look at the degree of impact business related factors may have on both the categories of financial institutions and the differences thereof.

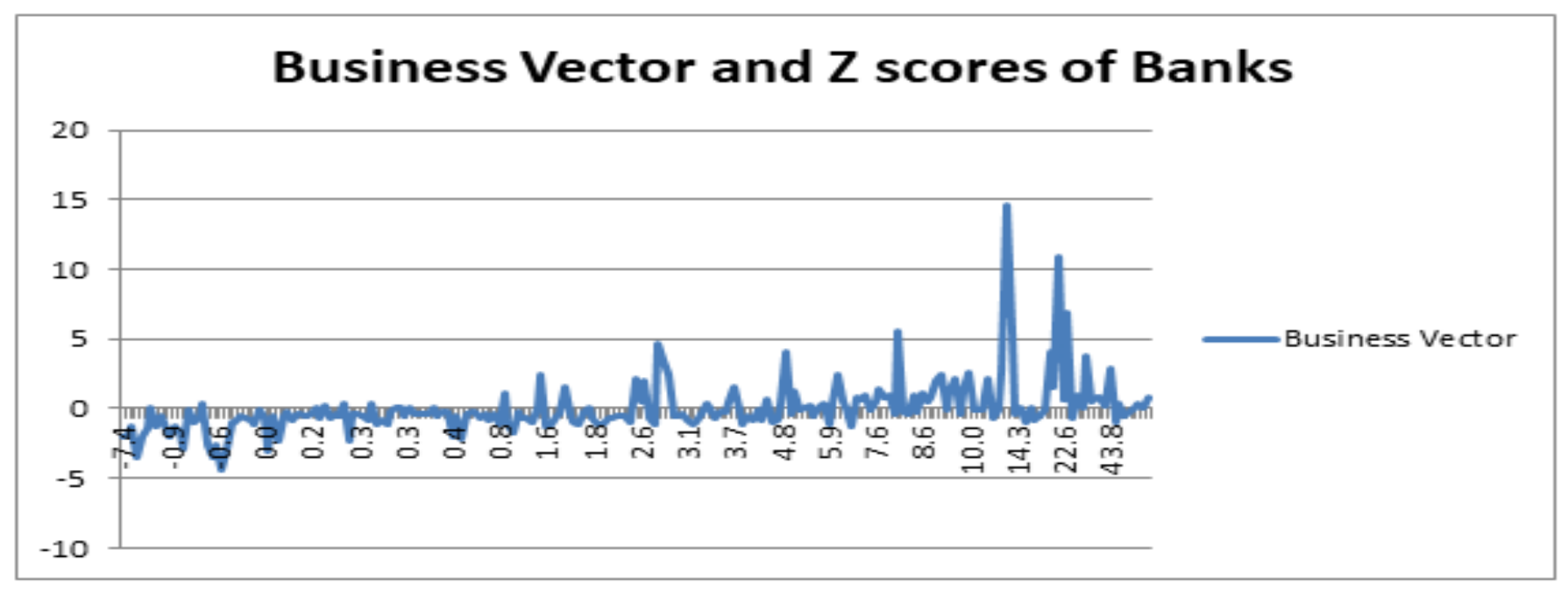

FIGURE: 5 BV VS Z-SCORES 


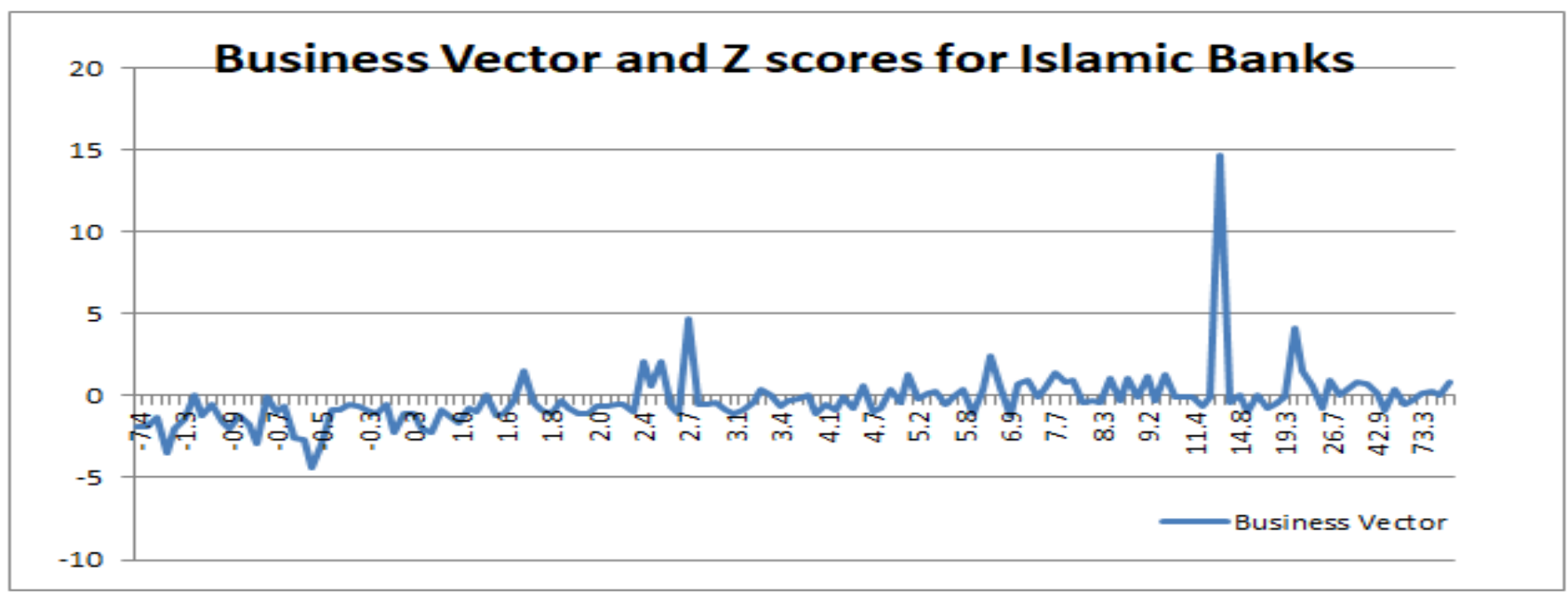

Figure: 6 BV vs Z-Score for IB

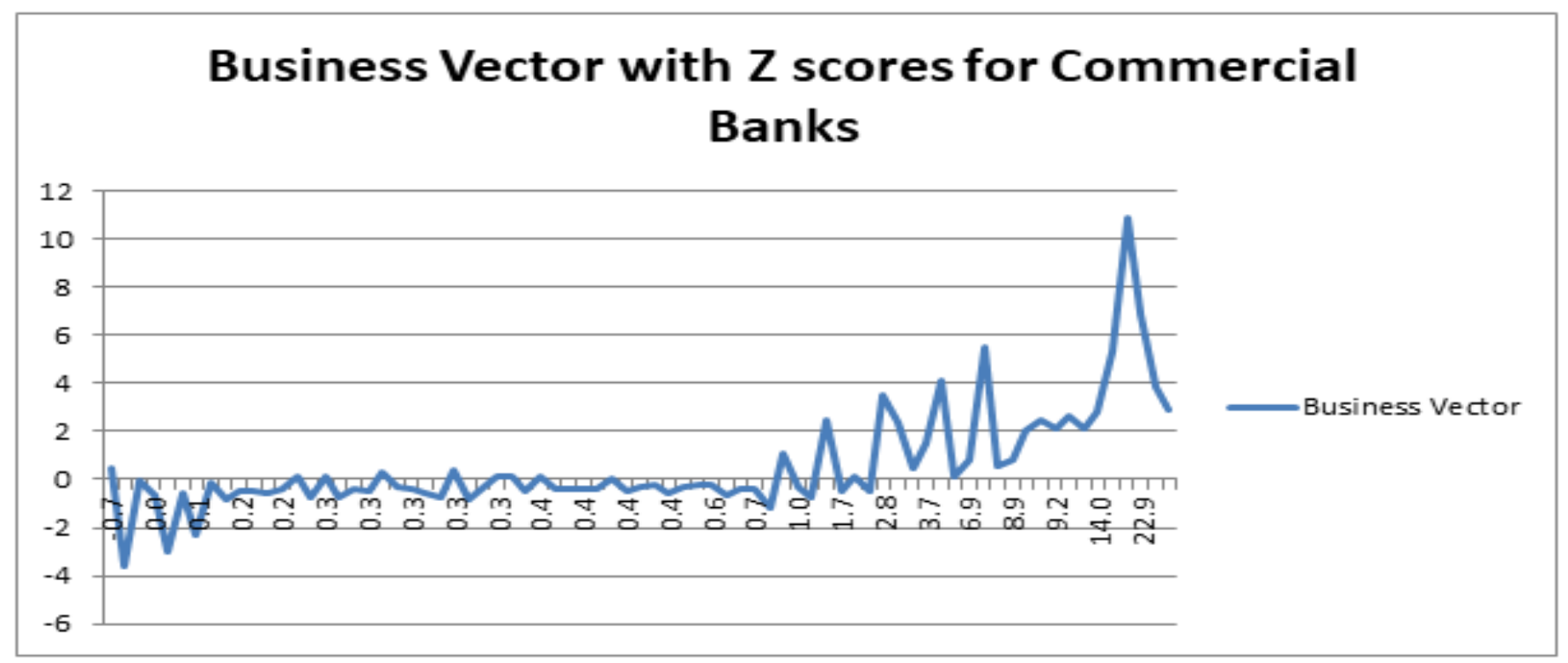

Figure: 7 BV vs Z-Score for CB

Business vector for Conventional commercial banks with respect to z-score shows more variance as compared to the BV to z-score of Islamic Banks. When compared with gradual improvements in business related factors of Islamic banks with respect to z-scores, or vice versa, Conventional banks seem to exhibit high vulnerability.

\section{Conclusion}

This study took into consideration the LCR of Islamic and Conventional Commercial banks and discovered that Conventional commercial banks operated on a significantly higher liquidity frontier than the Islamic banks. Most Islamic banks started with higher liquidity, but with the passage of time, there was a downward trend observed in liquidity ratio, primarily because at initiation all banks have highly liquid assets, its only after operational corrections that liquidity ratios are adjusted at an optimal level. Amongst the factors affecting liquidity most were Return on Equity (ROE) and Weighted Capital Adequacy Ratio (CARWTD). However, it was noticed that none of the business specific factors predicted liquidity levels to an illustrious extent. The reason behind this was excessive management of the liquidity ratio by the banks. In most of the countries, banks are expected to comply with regulations that require maintenance of a certain liquidity level, and banks try to manage these by mauling the cash 
inflows or cash outflow components of the Liquidity Conversion Ratio. Therefore, it is highly unlikely that bank performance would dictate the LCR.

Long term resilience quotient of banks was determined by $\mathrm{z}$-scores of the comparative regimes. The average $\mathrm{z}$ scores of Islamic banks were quite high, placing them ina safer zone than Commercial banks.

Not only did Islamic banks have a higher z-score, but also they maintained a less volatile range of z-score as compared to their conventional counterparts. The Islamic banks showed multiple equilibria and extended period of stability as compared to Commercial banks.

\section{References}

(2004). Basel II: International Convergence of Capital Measurement and Capital Standards: a Revised Framework. Bank for International Settlements.

(2006). Basel II: International Convergence of Capital Measurement and Capital Standards: A Revised Framework - Comprehensive Version. Bank for International Settlements.

(2007). Bangladesh-Crisis averted for now.. Emerging Markets Monitor.

(2009). Islamic Banking - Not Escaping The Crisis-Turkey Commercial Banking Report. Business Monitor International Ltd.

(2009). Islamic Banking - Not Immune To The Crisis-Egypt Commercial Banking Report. Business Monitor International Ltd.

(2009). Islamic Banking Overview-Iran Commercial Banking Report. Business Monitor International Ltd.

(2010). Basel III: International framework for liquidity risk measurement, standards and monitoring. Bank for International Settlements.

(2011). Asia Banking Sector Outlook-China Commercial Banking Report Q3. Business Monitor Ltd.

(2011). Islamic Banking Industry. Economic Review.

(2011). Saudi Arabia Commercial Banking Report Q2. Business Monitor International Ltd.

Abduh, M., \& Omar, M. A. (2012). Islamic banking and economic growth: the Indonesian experience. International Journal of Islamic and Middle Eastern Finance and Management, Vol. 5 No. 1,pp 35-47.

Barth, J. R. (2001). Banking systems around the globe; Do regulation and ownership affect performance and stability? In F. S. Mishkin, Prudential Supervision; What works, what doesnt. National Bureau of Econoic Research.

Beck, T., Demirgüç-Kunt, A., \& Merrouche, O. (2013). Islamic vs. conventional banking: Business model, efficiency and stability. Journal of Banking \& Finance 3, 433-447.

Berger et al. (1987). Competitive viability in banking: Scale, scope and product mix economies. Journal of Monetary Economics, 501-520.

Bokpin, G. A. (2013). Ownership structure, corporate governance and bank efficiency: an empirical analysis of panel data from the banking industry in Ghana. Corporate Governance.

Bourke, P. (1989). Conventration and other determinants of bank rofitability in Europe. Journal of Banking and Finance, Vol.1:65-79.

C.S.Holing. (1973). Resilience and stability of ecosystems. Annual review of ecology and semantics, Vol4: 1-23.

Cole, R. A., \& Gunther, J. W. (1993). Separating the likelihood and timing of bank failure. Journal of Banking and Finance, 1073-1089.

Demirguc-Kunt, A., \& Huizinga, H. (1989). Determinants of commercial bank interest margins and profitability: some international evidence. World Bank Economic Review, 379-408.

Farook, S., Hassan, M. K., \& Clinch, G. (2012). Profit distribution management by Islamic banks: An empirical investigation. The Quarterly Review of Economics and Finance, 333-347.

Hasan, M., \& Dridi, J. (2010). The Effects of the Global Crisis on Islamic and Conventional Banks :A Comparative Study. IMFWorking Papers Series.

Hesse H, Čihák M (2007) Cooperative banks and financial stability. IMF Working Paper No. 07/02. International Monetary Fund, Washington

Hussein, K. A. (2004). Banking efficiency in Bahrain : Islamic vs Conventional banks. Islamic Development Bank. 
J.P. Bonin et al. (2005). Bank performance, efficiency and ownership in transition countries. Journal of banking and finance, 31-53.

Eton, W. R. (1999). Does faster loan growth lead to higher loan losses? Journal of Banking and Finance, 14711481.

Molyneux, P., \& Thornton, J. (1992). Determinants of European bank profitability: A note. Journal of Banking and Finance, Vol.16: 1173-1178.

Revell, J. (1979). Inflation and Financial institutions. Financial Times, London.

Short, B. (1979). The relation between commercial bank profit rates and concentration in Canada, Western Europe and Japan. Journal of banking and finance, 209-219.

Siddiqui, M. N. (2006). Islamic banking and finance in theory and practise; The survey of state of the Art. Islamic Economic Studies.

Warde, I. (2000). Islamic Finance in Global Economy. Edinburgh University Press. 
